\title{
História e representação literária: \\ Uma reflexão sobre Os demônios de Loudun, de Aldous Huxley
}

\author{
History and literary representation: a reflection on \\ Aldous Huxley's The devils of Loudun \\ Shirley de Souza Gomes CARREIRA ${ }^{1}$ \\ ABEU - Centro Universitário (UNIABEU)
}

\begin{abstract}
RESUMO: Em Os demônios de Loudun, Aldous Huxley traz à baila um acontecimento ocorrido em Loudun, no século XVII, utilizando estratégias que podem ser equiparadas às técnicas da micro-história, apesar de a obra ter sido escrita em 1952, cerca de três décadas antes dos estudos pioneiros de Carlo Ginzburg e Giovanni Levi. Para fins desta análise, abordaremos o conceito tradicional de romance histórico, bem como os diálogos entre ficção e história em suas diversas modalidades, focalizando, também, o conceito, a origem e as técnicas da microhistória, de modo a apontar seus pontos de convergência com o romance de Huxley.
\end{abstract}

PALAVRAS-CHAVE: Huxley. Romance historic. Micro-história.

ABSTRACT: In The devils of Loudun, Aldous Huxley brings up an event that took place in Loudun, in the seventeenth century, using strategies that can be associated with the techniques of micro-history, although the book was written in 1952, nearly three decades before the pioneering studies by Carlo Ginzburg and Giovanni Levi. For purposes of this analysis, we discuss the concept of traditional historical novel, as well as dialogues between fiction and history in their diverse forms, focusing, too, the concept, origin and techniques of micro-history, to present their points of convergence with Huxley's novel.

KEYWORDS: Huxley. Historical novel. Micro-history.

Toda interpretação concorda com o modelo de pensamento dominante. Aldous Huxley

\section{Introdução}

Em Tempo e narrativa, Paul Ricouer (1997, p. 329) afirma que "a narrativa de ficção é quase histórica, na medida em que os acontecimentos irreais que ela relata são fatos passados para a voz narrativa que se dirige ao leitor", assemelhando-se, assim, a acontecimentos passados, registrados pela historiografia. Ao fazê-lo, Ricouer (1997) se reporta à narrativa de ficção em geral, sem privilegiar um gênero específico, diferentemente do que Lukács faz em O Romance histórico (2011). Nesta obra, o autor define o romance como um gênero que surgiu na estética do romantismo, muito embora tenha características que podem fazer com que seja interpretado como antirromântico, posto que está intimamente ligado à ascensão da burguesia, às novas mudanças

${ }^{1}$ Doutora em Literatura Comparada. Professora Titular do UNIABEU; Curso de Letras; Rio de Janeiro, RJ.shirleysgcarr@gmail.com 
econômicas, sociais e políticas do momento e à conscientização das pessoas em relação à relevância da história do próprio país e do mundo.

De certa forma, o modo de narrar a ficção sempre esteve atrelado à maneira de pensar a historiografia, e esta, ao refletir sobre o processo de elaboração da narrativa histórica, passou por mudanças significativas. Em toda a discussão que promoveu tais mudanças, o questionamento primordial girou em torno da "veracidade" das narrativas históricas, uma vez que o passado é narrado através de textos.

$\mathrm{Na}$ efervescência da oposição da École des Annales (BRAUDEL, 1969) à tradicional história dos acontecimentos (historie événementielle), em prol de uma história das estruturas, ou seja, substituindo o tempo breve da história dos acontecimentos pelos processos de longa duração, outras formas de narrar a História foram surgindo, entre elas a micro-história e a micronarrativa; a primeira, baseada na redução da escala da observação, com focalização em um determinado acontecimento empírico e no estudo intensivo do material documental, e a segunda, na narração de uma história sobre as pessoas comuns no local em que estão instaladas.

Assim, a literatura pode apropriar-se dos fatos históricos em pontos de vista diferenciados: o da "história vista de cima", ou seja, numa ótica política, que privilegia o olhar do dominador, ou da "história vista de baixo", que dá primazia à ótica dos subalternos; em uma perspectiva que pode ser macro ou microhistórica.

A proposta deste artigo é refletir sobre a ficcionalização de um acontecimento ocorrido em Loudun, no século XVII, no romance Os demônios de Loudun, de Aldous Huxley (1986), e o modo como a estrutura da narrativa aproxima-se das estratégias narrativas da micro-história, apesar de a obra ter sido escrita em 1952, cerca de trinta anos antes do surgimento da coleção dirigida por Carlo Ginzburg e Giovanni Levi, denominada Microstorie, publicada pela editora Einaudi, entre 1981 e 1988.

\section{A narrativa ficcional da história e suas possibilidades}

Narrar a História tem sido um desafio e uma atração para os romancistas, que, apesar da licença criativa que a ficção lhes concede, são obrigados a empreender pesquisas que envolvem documentos históricos, dentre outras fontes, que lhes permitam não apenas construir o enredo de seus romances, mas também contextualizá-los condignamente.

A literatura do século XX, especialmente a da segunda metade, nos oferece muitos exemplos de romances históricos, bem como narrativas que podem ser consideradas como pertencentes a um subgênero, denominado por Linda Hutcheon (1991) "metaficção historiográfica". Claro está que há diferenças entre o romance histórico tradicional e a metaficção historiográfica, passando principalmente por questões que envolvem o reconhecimento textual do estatuto de ficção.

O romance histórico surge no século XIX, segundo estudiosos do gênero, como Lukács (2011), com a publicação dos romances de Sir Walter Scott: Waverley, em 1814, e Ivanhoe, em 1820, entre outros. A narrativa de Scott foi inovadora no que diz respeito à forma e ao conteúdo da expressão literária tradicional de seu tempo, moldando o curso do romance histórico, disseminando o historicismo e influenciando o trabalho de outros escritores.

Para Lukács (2011), uma das características fundamentais para a existência dos romances históricos é a utilização de dados verídicos para a constituição ambiente. 
Tradicionalmente, eles representariam um processo apresentado por meio de um universo específico generalizante, tendo como pano de fundo um ambiente histórico totalmente reconstruído, em que a ação se desenvolveria num passado anterior ao presente do escritor, por meio de personagens que constituiriam tipos bem marcados, sínteses do geral, relegando, na maioria das vezes, às figuras históricas papeis secundários. A sua presença no texto serviria ao propósito de ajudar a compor ou contar a história e a situar a época focalizada, agindo de acordo com a mentalidade do seu tempo. A descrição detalhada de lugares e personagens seria uma estratégia para a obtenção de uma veracidade histórica.

Em contraposição à visão tradicional de Lukács, Joseph Turner (apud MARINHO, 1999), estabelece três tipos de escrita histórica, objetivando a análise dos romances do século XX: os romances históricos documentados, que empregam personagens fictícias e reais; os romances históricos "disfarçados", claramente construídos como uma recriação histórica, mescla de documento e invenção; e os romances históricos inventados, em que o narrador desempenha o papel de um historiador, fingindo estar relatando uma realidade extratextual.

A metaficção historiográfica, por sua vez, tem por objetivo "reescrever ou reapresentar o passado na ficção e na história" (HUTCHEON, 1991, p. 147), revelandoo ao presente e impedindo-o de ser conclusivo e teleológico. Os romances pósmodernos, então, se apresentam como uma ruptura com o aspecto totalizante, que revela a imposição de sentido, presente nos romances históricos tradicionais. Paralelamente, a metaficção historiográfica expõe-se claramente como ficção:

Com esse termo, refiro-me àqueles romances famosos e populares que, ao mesmo tempo, são intensamente autorreflexivos e mesmo assim, de maneira paradoxal, também se apropriam de acontecimentos e personagens históricos [...] Na maior parte dos trabalhos de crítica sobre o pós-modernismo, é a narrativa - seja na literatura, na história ou na teoria - que tem constituído o principal foco de atenção. A metaficção historiográfica incorpora todos esses três domínios, ou seja, sua autoconsciência teórica sobre a história e a ficção como criações humanas (metaficção historiográfica) passa a ser base para seu repensar e sua reelaboração das formas e dos conteúdos do passado.

(HUTCHEON, 1991, p. 21-22).

Diferentemente do romance histórico tradicional, os protagonistas são os marginalizados, favorecidos por uma ótica "ex-cêntrica", relegando às personagens marcadas no antigo modelo um papel que é visivelmente ironizado. A eles cabe uma narrativa de múltipla focalização, de modo a evidenciar a relativização e a precariedade das narrativas sobre o passado.

O que dizer, no entanto, dos romances que efetivamente trazem a figura histórica para o primeiro plano, que se fixam de fato no acontecimento empírico, fazendo-se valer dos registros historiográficos, dos documentos, na construção da narrativa ficcional? Parece-nos haver uma lacuna na teoria sobre as narrativas ficcionais da história, particularmente entre a concepção do romance histórico tradicional e a metaficção historiográfica, que não parecem dar conta de todas as narrativas associadas ao gênero. 
Na medida em que alguns romances ditos "históricos" aproximam-se dos relatos inerentes à micro-história e à micronarrativa, surge a necessidade de uma teorização que os privilegie.

\section{A história como tema em Os demônios de Loudun}

A leitura de $O$ queijo e os vermes, de Carlo Ginzburg (1987) torna perceptível o fato de que o processo de construção de alguns romances que abordam fatos históricos apresenta-se similar àquele da micro-história.

Segundo Ginzburg (1987), o desânimo provocado pela pesquisa de fontes escritas, a partir da evidência da ligação de seus autores às classes dominantes, pode ser superado pela pesquisa dessas mesmas fontes em uma outra perspectiva: a de como esses registros podem fornecer dados sobre a opressão sofrida pelos subalternos. Podese dizer, assim, que "a micro-história opera com escala de observação reduzida, exploração exaustiva de fontes, descrição etnográfica e preocupação com a narrativa literária" (GUIMARÃES, 2003, p.317). Dedica-se a "temáticas ligadas ao cotidiano de comunidades específicas - referidas geográfica ou sociologicamente -, às situaçõeslimite e às biografias ligadas à reconstituição de microcontextos ou dedicadas a personagens extremos, geralmente vultos anônimos, figuras que por certo passariam despercebidas na multidão" (GUIMARÃES, 2003, p. 317).

Em $O$ queijo e os vermes (1987), a pesquisa do historiador, que, a princípio, buscava informações sobre julgamentos de casos de bruxaria, o levou à história de um moleiro perseguido pela Inquisição no século XVI. Baseando-se principalmente nos escritos promovidos pela Inquisição, o autor nos concede uma visão privilegiada a respeito dos pensamentos e conceitos próprios estabelecidos pelo moleiro, também conhecido por Menocchio, e o posterior processo inquisitório que o condenou.

Em Os demônios de Loudun, Aldous Huxley (1986) procede também a uma investigação histórica, a fim de construir o seu romance, que tem como tema a morte do Padre Urbain Grandier, em 18 de agosto de 1634, após ser julgado e sentenciado pela Inquisição em um processo em que era acusado de bruxaria. Se por um lado, não é possível dizer que Grandier fazia parte de um grupo de excluídos, como Menocchio, por outro, a sua história revela os bastidores de uma querela de natureza política, travestida de questão religiosa. Os absurdos relacionados ao processo que culminou com a condenação de Grandier foram o ponto de atração para o autor.

\subsection{A história de Urbain Grandier}

Urbain Grandier nasceu em Bouère e, tendo estudado ciências com seu pai Pierre e seu tio Claude Grandier, que eram astrólogos e alquimistas, foi admitido, aos doze anos, no colégio Jesuita de Bordeaux, recebendo uma educação tradicional. Tinha, no entanto, o dom da oratória e muita facilidade no aprendizado de idiomas. Devido a essas habilidades, foi incitado por seus professores a praticar a pregação, a fim de aprimorar seus dons. Assim que tomou os votos, foi designado para a paróquia de SaintPierre, em Loudun. 
Tal honraria suscitou críticas e inveja. Além disso, o padre Grandier possuía outros predicados invejáveis. A eloquência dos seus sermões tinha atraído à sua igreja grande parte das congregações de outras comunidades religiosas. Dono de uma beleza incomum e de uma inteligência singular, o que decerto teria sido responsável pelo seu brilho em uma cidade grande, como Paris, foi responsável por sua derrocada em Loudun. Um de seus mais ferozes opositores era La Rocheposay, o bispo de Poitiers.

Grandier ignorava os votos de celibato, relacionando-se sexualmente com várias mulheres. Em 1632, quando as freiras do convento das Ursulinas apresentaram sintomas de uma histeria coletiva, então interpretada como possessão, o padre foi acusado de ter invocado demônios, Asmodeus e Zabulon, para que elas fossem forçadas a cometerem atos indecorosos com ele.

Na noite de 12 de outubro, várias freiras, entre elas a Madre Superiora, foram atormentadas por espectros e visões aterradoras, sendo submetidas ao exorcismo pelo Cônego Mignon e seu assistente, Padre Barré. Os demônios foram expulsos de todas, com exceção da Madre Superiora e de outra religiosa, Irmã Claire (BRUCE, 2009) Tendo concluído que o caso delas não era apenas de possessão, mas envolvia uma força ainda maior, Mignon decidiu inquirir a entidade que as possuía, obtendo, assim, o nome de Grandier. A revelação espalhou-se, para contentamento de Mignon.

O fato adquiriu proporções de escândalo e só foi momentaneamente contido graças à intervenção do Arcebispo de Bordeaux, amigo de Grandier. No entanto, após a chegada de Laubardemont, um oficial enviado por Richelieu, que, por ironia do destino, era parente da Madre Superiora, as crises recomeçaram. Obviamente, Laubardemont interessou-se pelos acontecimentos e Mignon não perdeu tempo, revelando-lhe que o responsável era um padre que recentemente havia satirizado Richelieu de tal modo que o tornara alvo do ridículo perante toda a corte.

As notícias tiveram o efeito esperado e Richelieu ordenou a prisão de Grandier, conferindo a Laubardemont poderes para inquiri-lo. Grandier teve seus bens confiscados e foi aprisionado em uma das propriedades de Mignon, começando, assim, o seu processo de julgamento.

As testemunhas que tentavam favorecer Grandier eram ameaçadas, enquanto que as que depunham contra ele eram fartamente recompensadas. Durante os depoimentos, muitas provas falsas de possessão demoníaca induzida por Grandier foram forjadas; chegando ao cúmulo de, como registra Bruce (2009), no momento em que o demônio que "possuía" a Madre Superiora cumpria a promessa de levantar o chapéu de Mignon, alguns expectadores descrentes terem surpreendido o "autor do feito", ou seja, um homem, ao invés do diabo, manipulando uma corda com um anzol na ponta. Ao ser descoberto, o homem fugiu, impossibilitando a comprovação da inocência de Grandier.

O fato é que, anteriormente, em 5 de junho de 1630, Grandier enfrentara uma acusação e julgamento por comportamento indecoroso, que resultara em punição, e seu passado depunha contra ele.

Sessenta testemunhas fizeram acusações de adultério, sacrilégio e outros crimes cometidos mesmo em recintos sagrados, dentro da Igreja. O processo de Urbain Grandier foi marcado por contradições. É fato que várias religiosas retiraram as denúncias e revelaram terem sido "instruídas" por superiores, mas de nada adiantou. O 
réu afirmou sua inocência, mesmo submetido a torturas, e manteve esta posição até o momento final, na fogueira. Nos meses seguintes à morte de Grandier, vários de seus acusadores morreram vitimados por doenças misteriosas e as freiras continuaram a padecer de convulsões.

No processo jurídico-eclesiástico contra Grandier, consta como prova conclusiva um pacto, ou seja, um documento encontrado entre os papéis do réu devassados depois de sua prisão, pretensamente assinado com sangue por ele e pelo demônio Asmodeus.

O pacto (figura 1) dizia:

Meu Senhor e Mestre, tenho-o como meu Deus; prometo servi-lo enquanto viver e, desde esta hora, renuncio a todos os outros deuses e Jesus Cristo e Maria e todos os Santos do Céu e à Igreja Católica Apostólica Romana e a todo o bem e preces que possam ser feitos por mim. Prometo adorá-lo e prestar-lhe homenagem pelo menos três vezes por dia e fazer o máximo de mal possível e levar ao mal tantas pessoas quanto possível; renuncio de coração ao Cristo, ao batismo e a todos os méritos de Jesus Cristo; no caso de desejar mudar, dar-lhe-ei meu corpo e minha alma e minha vida como garantia, tendo entregue tudo isso para sempre sem qualquer vontade de arrependimento. Assinado: Urbain Grandier, com seu sangue. (GOLSDMISTH, 1887, p. 6-7).

Grandier, mesmo sofrendo cruel tortura, jamais confessou ser o responsável pelos acontecimentos em Loudun.

O caso das freiras de Loudun despertou controvérsias e alguns estudiosos do caso, dentre eles Huxley (1986), verificaram ser, no mínimo, curioso, o fato de que as denúncias só foram feitas após Grandier ter se recusado a assumir a tarefa de diretor espiritual do convento.

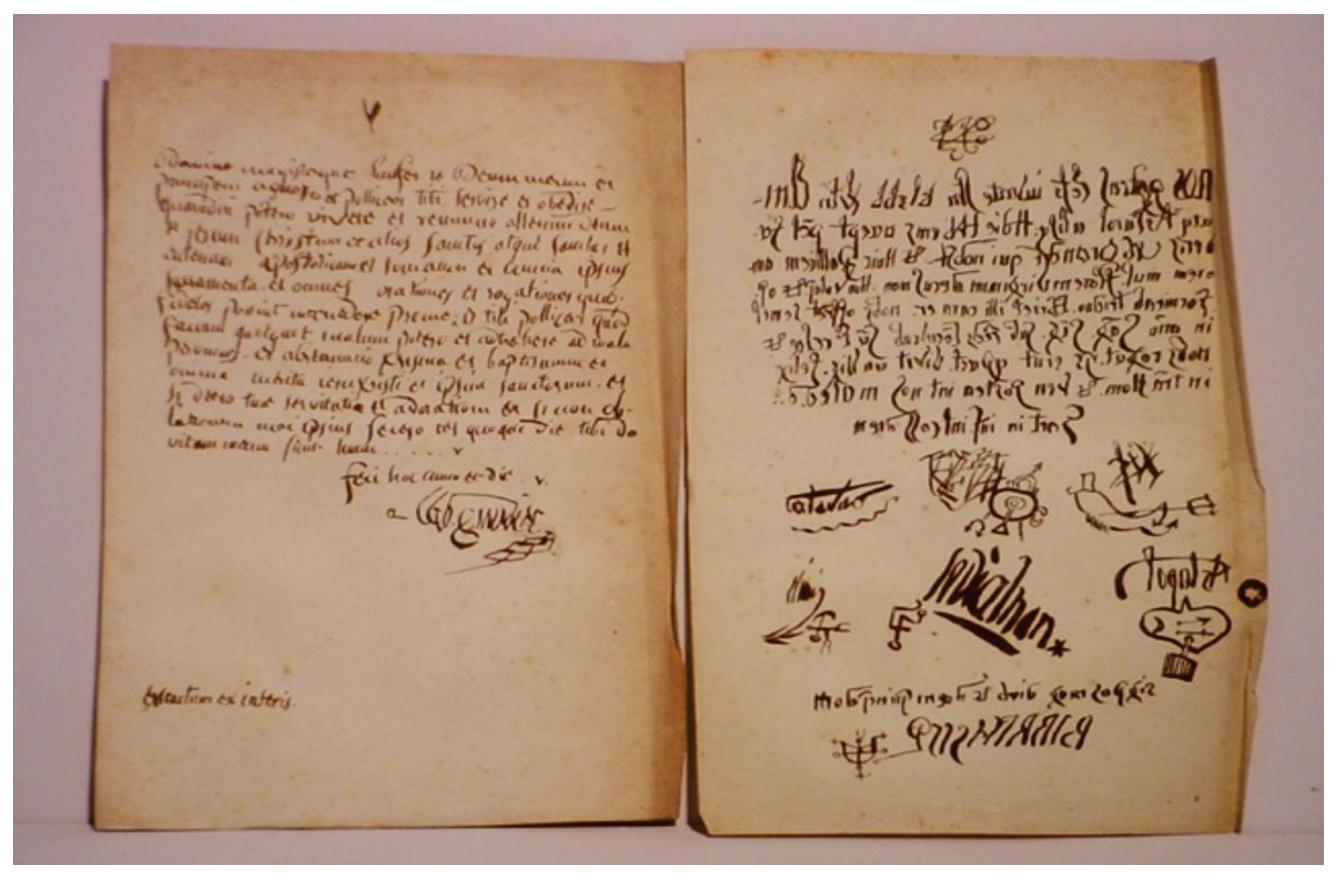

Figura 1 - Pacto de Grandier 
Historiadores modernos conseguiram provar que a caligrafia não era de Grandier, mas de Jeanne des Anges, a Madre Superiora do convento das Ursulinas.

\section{A ficção reconta a história}

A extensa pesquisa histórica realizada por Huxley (1986) sobre o caso dos demônios de Loudun é descrita em uma bibliografia ao fim do romance, e dentre as fontes mencionadas encontram-se: Historie des diables de Loudon (1693), "Urbain Grandier", ensaio de Jules Michelet, Urbain Grandier at lêspossédées de Loudun (1880), Documents pour servir à l'historie médicale des possédées de Loudun (1876), Soeur Jeanne des anges, autobiographie d'une histérique possédée (1886), a única edição da narrativa feita pela prioresa em 1644, que também contém inúmeras cartas escritas por ela para o padre Saint-Jure, e Lettres spirituelles du P. Jean-Joseph Surin (1926), que contém a autobiografia do padre Surin.

Diferentemente de outros relatos romanceados de fatos históricos, Os demônios de Loudun apresenta uma estrutura híbrida, em que os capítulos que narram a história, que culmina com a morte de Urbain Grandier, são intercalados com digressões de um narrador do século XX, que se debruça crítica e reflexivamente sobre o passado e o narra a partir de fontes documentais que oferecem diferentes versões para $o$ acontecimento narrado.

Chartier (1994, p. 2) afirma que "cada micro-história pretende reconstruir, a partir de uma situação particular, normal porque excepcional, a maneira como os indivíduos produzem o meio social, por meio de alianças e confrontos, através das dependências que os ligam ou dos conflitos que os opõem".

Assim como Ginszburg (1987), que, no prefácio da edição italiana de $O$ queijo $e$ os vermes, afirma a possibilidade de obter um quadro rico das ideias, aspirações e sentimentos de Domenico Scandella, o Menochio, por meio da leitura dos dois processos abertos contra ele, de documentos e textos escritos pelo próprio, Huxley (1986) recria diante do leitor a vida de Urbain Grandier, suas crenças e ações, a partir da leitura de documentos e obras sobre o julgamento, buscando analisá-los com o olhar do homem do século XX.

O relato de Huxley (1986) expõe os bastidores da Inquisição e a sua reflexão sobre a histeria coletiva que acometeu as Ursulinas. Quando se reporta ao século XVII, o narrador assume a voz do historiador:

Grandier viveu no cinzento alvorecer do período que poderia ser chamado de Idade da Decência. Durante toda a Idade Média e no início da Moderna, o abismo entre a doutrina católica oficial e a prática efetiva dos sacerdotes fora enorme e, a julgar pelas aparências, intransponível. É difícil encontrar um escritor da Idade Média ou da Renascença que não tenha como certo que a maioria dos membros que compõem o clero, do mais poderoso prelado ao mais humilde frade é profundamente libertina. A corrupção eclesiástica levou à Reforma, que, por sua vez, gerou a Contra-Reforma. (HUXLEY, 1986, p. 12).

O tom da narrativa assemelha-se bastante ao do livro de Ginzburg (1987, p.46): 
Dois grandes eventos históricos tornaram possível um caso como o de Menocchio: a invenção da imprensa e a Reforma. A imprensa lhe permitiu confrontar os livros com a tradição oral em que havia crescido e lhe forneceu as palavras para organizar o amontoado de ideias e fantasias que nele conviviam. A Reforma lhe deu audácia para comunicar o que pensava ao padre do vilarejo, conterrâneos, inquisidores - mesmo não tendo conseguido dizer tudo diante do papa, dos cardeais e dos príncipes, como queria. As rupturas gigantescas determinadas pelo fim do monopólio dos letrados sobre a cultura escrita e do monopólio dos clérigos sobre as questões religiosas haviam criado uma situação nova, potencialmente explosiva. Mas a convergência entre as aspirações de uma parte da alta cultura e as da cultura popular já tinha sido declarada de maneira definitiva mais de meio século antes do processo de Menocchio - quando Lutero condenara com ferocidade os camponeses em revolta e suas reivindicações.

No romance de Huxley (1986), os comentários do narrador sobre os fatos históricos são, muitas vezes, acompanhados de notas de rodapé, com indicação das fontes: "As citações que se seguem foram extraídas do resumo de H. C. Lea sobre a situação da Igreja francesa depois do Concílio de Trento" (HUXLEY, 1986, p. 13, nota de rodapé).

A exposição das fontes documentais também é feita na obra de Ginzburg (1987, p.11):

O queijo e os vermes pretende ser uma história, bem como um escrito histórico. Dirige-se, portanto, ao leitor comum e ao especialista. Provavelmente apenas o último lerá as notas, que pus de propósito no fim do livro, sem referências numéricas, para não atravancar a narrativa.

Em Os demônios de Loudun (1986), a ordem cronológica dos acontecimentos na diegese é interrompida, por vezes, pelo narrador moderno, que antecipa os eventos e os compara não apenas a outros do mundo contemporâneo, mas também menciona obras da literatura à medida que tece suas conjeturas sobre os eventos narrados, como nesta referência a um dos antagonistas de Grandier, o barão de Laubardemont: "Em aparência e modos, o barão tomava como modelo, duzentos e tantos anos antes de seu surgimento, o Uriah Heep de Dickens." (HUXLEY, 1986, p. 65).

Semelhantemente, Ginzburg (1987) narra tecendo reflexões e conexões com obras seminais como Histoire de la folie, de Foucault, e L' oeuvre de Prançois Rabelais et la culture populaire au Moyen Age et sous la Renaissance, de Bakhtin:

Mas o limite do belíssimo livro de Bakhtin talvez seja outro: os protagonistas da cultura popular que ele tentou descrever - camponeses, artesãos - nos falam quase só através das palavras de Rabelais. É justamente a riqueza das perspectivas de pesquisa indicadas por Bakhtin que nos faz desejar, ao contrário, uma sondagem direta, sem intermediários, do mundo popular. (GINZBURG, 1987, p. 22)

Para Ginzburg (1987, p.13), "entre a cultura das classes dominantes e a das classes subalternas existiu, na Europa préindustrial, um relacionamento circular feito de influências recíprocas, que se movia de baixo para cima, bem como de cima para baixo [...]", que é o resumo do que foi proposto por Mikhail Bakhtin. 
O trânsito de valores entre as classes é abordado por Huxley (1986, p. 18) em sua narrativa:

Tal era, então, a espécie de mundo no qual o novo pároco fora criado - um mundo no qual os tradicionais tabus sexuais pouca influência exerciam sobre a maioria ignorante e necessitada, nem eram de demasiada importância para seus superiores; um mundo onde as duquesas diziam piadas como a ama de Julita, e a palestra das grandes damas era uma tosca e enfadonha imitação da Matrona de Bath.

Ao narrar como Jean-Jacques Bouchard, um contemporâneo de Grandier, seduz e corrompe uma jovem criada de quarto de sua mãe, o narrador de Huxley (1986, p. 15) manifesta a sua ironia:

A moça, na primeira vez em que deu por ela, era piedosa e quase hostil em sua castidade. Com a perseverança e a perspicácia de um Pavlov, Bouchard recondicionou de tal forma aquele produto da fé irrestrita, que ela se tornou finalmente uma devota da filosofia natural, tão pronta a ser observada e submetida a experiências quanto a empreender pesquisas por iniciativa própria.

Urbain Grandier é retratado como um jovem de boa aparência, dotado do dom da retórica e extremamente sedutor.

Desde o princípio, a opinião pública a respeito do novo pároco estava nitidamente dividida. A maioria do sexo frágil, mais devoto, aprovou-o. $\mathrm{O}$ último cura fora um decrépito João-ninguém. Seu sucessor era um homem no vigor da mocidade, alto, forte, com um ar de sóbria autoridade, e até mesmo (segundo um contemporâneo) majestático. Seus olhos eram grandes e negros, e sob o seu barrete de clérigo os abundantes cabelos eram pretos e ondulados; a fronte, alta; o nariz, aquilino; os lábios, rubros, cheios e expressivos. Uma elegante barba à Van Dyck adornava-lhe o queixo, e sobre o lábio superior o pároco usava um fino bigode [...] Para os olhos pós-faustianos, seu retrato sugeria Mefistófeles em trajes clericais, mais robusto, amistoso e só um pouco menos inteligente. (HUXLEY, 1986, p. 12)

O déficit de inteligência é explicado pelo narrador como uma extrema dificuldade de refrear a vaidade e o temperamento explosivo: "Em vez de tentar chegar a um acordo com seus inimigos, o pároco empenhava-se por todos os meios a seu alcance em exacerbar suas hostilidades. E sua aptidão para isso atingia quase a genialidade". (HUXLEY, 1986, p. 240).

Guardadas as devidas proporções, Grandier promove um embate com a Igreja que é, de certa forma, análogo ao de Menocchio. Este, em sua tentativa de formular ideias pessoais e um confuso pensamento teológico deformava involuntariamente os livros que lia: 
Foi o choque entre a página impressa e a cultura oral, da qual era depositário, que induziu Menocchio a formular - para si mesmo em primeiro lugar, depois aos seus concidadãos e, por fim aos juízes - as 'opiniões [...] [que] saíram da sua própria cabeça' (GINZBURG, 1987, p. $89)$.

A ousadia de Grandier era de outra ordem, pautada na ambição do poder. Suas atitudes não divergiam do padrão da época, em que a distância entre a teoria e o comportamento manifesto era enorme no que diz respeito à religião, porém deleitava-se em desafiar os que estavam ao seu redor. Os registros, cartas e documentos da época permitiram a Huxley (1986, p. 23) recuperar detalhes desse embate.

Quase imediatamente depois de sua chegada em Loudun, Grandier envolveu-se em uma série de rixas inconvenientes, mas em sua opinião profundamente divertidas [...] por uma questão de prudência elementar, não menos que por princípios cristãos, o pároco deveria ter-se empenhado ao máximo para reconciliar-se com os inimigos que o cercavam. Contudo, apesar de todos os anos transcorridos com os jesuítas, Grandier estava ainda muito longe de ser um cristão; e, a despeito de todos os bons conselhos que recebia de D'Armanac e seus outros amigos, era incapaz de agir com prudência em situações onde estavam em causa suas paixões.

Ronaldo Vainfas (2002, p. 103), em Os protagonistas anônimos da história: microhistória, afirma que "a microhistória [...] apega-se obsessivamente às mínimas evidências que a documentação pode fornecer para dar vida a personagens esquecidos e desvelar enredos e sociedades ocultados pela história geral". É exatamente essa a perspectiva de Huxley (1986) em Os demônios de Loudun.

À medida que a narração prossegue, as histórias pessoais de outras personagens históricas vão se entrecruzando com a de Grandier. Assim, o romance aborda as biografias de Jean-Joseph Surin, padre que foi designado para tomar parte nos exorcismos das freiras ursulinas, e de Jeanne des Anges, a Madre Superiora do convento.

Ao retratar Grandier e Surin como produtos diferentes de um mesmo contexto social, Huxley (1986) focaliza dois lados de um mesmo desejo de autotranscendência. Em Grandier, ele se manifestava como uma necessidade constante de autoafirmação; em Surin, como a busca da perfeição cristã.

Enquanto Grandier granjeava muitos inimigos, dentre eles aquele que um dia viria a ser o responsável pela sua derrocada, o Cardeal Richelieu, Surin lutava com as tentações da carne, buscando superar-se.

Jeanne é descrita como uma mulher de corpo disforme, quase uma anã, que apesar de filha de um barão, portanto, privilegiada socialmente, fomentava um ressentimento crônico devido ao seu defeito físico. Era também uma mulher perspicaz e, quando foi enviada ao convento, soube tirar partido da situação, escondendo a sua natureza amarga e dada à zombaria como uma forma de agredir o mundo em torno. Assumindo o papel de religiosa dedicada, trabalhadora e devota, acabou por convencer a prioresa do convento a recomendá-la como sucessora. Nela, a sensação de poder era a única forma de autotranscendência. 


\begin{abstract}
Lançado contra os outros, nunca contra ela mesma, o escárnio da inconformada corcunda era um sintoma do desejo de vingar-se do destino, colocando as pessoas nos seus devidos lugares - e seus lugares, apesar das aparências, eram abaixo dela. Seu cinismo, motivado pela mesma ânsia de dominação, era uma convulsão mais impessoal, voltada contra tudo o que, pelos padrões correntes, era considerado solene, sublime e grandioso. (HUXLEY, 1986, p. 101-2)
\end{abstract}

$\mathrm{Na}$ composição da personagem, Huxley (1986) emprega descrições e comentários do próprio Surin, escritos à época dos exorcismos no livro Science expérimentale des choses de l'autre vie acquise en la possession des Ursulines de Loudun, de 1663.

Huxley (1986) opta por uma das versões existentes sobre o caso das ursulinas: a de que Jeanne de Befiel, ou Jeanne des Anges, então Madre Superiora do convento, tinha obsessão por Grandier, provavelmente alimentada pelo conhecimento de suas peripécias sexuais, ao sentir-se rejeitada quando Grandier recusa o convite para ser o orientador espiritual do convento, convida o cônego Jean Mignon, da Igreja de Santa Cruz, a ajudá-la em uma trama sórdida para vingar-se de Grandier.

Sua obsessão por ele fez com que passasse a ter sonhos sensuais e pecaminosos, em que Grandier lhe fazia carícias e propostas indecorosas, e ela os narrava às outras freiras, induzindo-as a ter sonhos semelhantes e a crer que estavam sendo assediadas por demônios.

Paralelamente, Mignon tirou proveito de uma brincadeira das freiras mais jovens no intuito de assustar as crianças e os idosos que acreditavam que o local do convento era assombrado.

Tendo descoberto a farsa, ele advertiu as jovens, ordenando-lhes, no entanto, que não a revelassem a ninguém, fomentando, assim, a crença de que aquele local estava sendo alvo do ataque de Satã.

Outras versões apontam Mignon como o mentor de uma vingança cuja causa era meramente política e os casos de possessão produzidos por meio de ameaças às freiras. Parte do romance se reporta aos estratagemas dos adversários de Grandier para obter a sua condenação e às reuniões secretas em que tramavam contra ele. Mignon aproveitouse do perfil de alguns dos membros da Igreja e convocou para ajudá-lo na tarefa um padre que "era um daqueles cristãos para quem o Demônio é incomparavelmente mais real e mais interessante que Deus" (HUXLEY, 1986, p. 116), vendo as marcas do Diabo em tudo: o Padre Barré.

Os exorcismos tiveram início e eram públicos, de modo a dar ao fato um tom sensacionalista. A tentativa de expulsar o demônio Asmodeus do corpo da prioresa Jeanne é curiosa, e bem sucedida: a aplicação de um enema de água benta. Sobre o fato, diz o narrador:

$\mathrm{Na}$ autobiografia que escreveu alguns anos mais tarde, a irmã Jeanne assegura-nos que, durante os primeiros meses de possessão, sua mente esteve tão confusa, que não podia lembrar de nada do que lhe havia acontecido. A declaração pode ser verdadeira - ou não. Há muitas coisas que gostaríamos de esquecer, que fazemos o máximo para abafar, mas que, na verdade, continuamos relembrando, e com muita nitidez. A seringa do Sr. Adam, por exemplo [...] (HUXLEY, 1986, p. 118). 
O narrador deixa claro que da obsessão por Grandier a prioresa resvalara para a dupla sensação de repulsa e prazer que esse tipo de tratamento lhe proporcionava; a ideia de ter se tornado um ser abjeto a livrava da condição de ser obrigatoriamente casta.

Durante os exorcismos, ela não era mais um ser; era apenas um objeto com intensas sensações. Isso era horrível, mas também maravilhoso - um ultraje, mas ao mesmo tempo uma revelação, e, no sentido literal da palavra, um êxtase, um sentimento muito além do eu odioso e familiar. (HUXLEY, 9186, p. 120).

O romance expõe o outro lado dos exorcismos, ou seja, as sensações causadas em ambos os atores, exorcista e exorcizada, o que, segundo afirma o narrador, só foi possível registrar graças ao hábito que o circunspecto Padre Surin tinha de escrever sobre tudo o que lhe acontecia. Dois anos depois, Surin foi convocado a tomar parte no processo, e, em seus escritos, mencionou as constantes tentações da carne, ao ver-se rodeado por mulheres histéricas, fazendo-o sentir-se o macho privilegiado, dominador e tirânico.

No capítulo 5, em relação à acusação contra Grandier, diz o narrador:

E então Grandier foi acusado de feitiçaria, e as ursulinas, de estarem possuídas por demônios. Ao lermos essas declarações, sorrimos; mas, antes que o sorriso se alargue ou estoure uma gargalhada, tentemos descobrir o significado atribuído a essas palavras na metade do século XVII. (HUXLEY, 1986, p. 127).

Em passagens como esta, que introduz uma longa digressão em que o narrador explica o impacto do Malleus Maleficarum na Idade Média, o narrador constrói um pacto com o leitor, convocando-o a acompanhá-lo em suas reflexões:

"Poucas pessoas, hoje em dia, acreditam no Diabo; mas muitas gostam de proceder como seus ancestrais o faziam na época em que o Demônio era uma realidade tão inquestionável quanto seu Oposto." (HUXLEY, 1986, p. 129).

O romance faz menção à tortura recomendada pelo Malleus, bem como às falsas promessas que eram permitidas aos exorcistas a fim de que obtivessem a confissão: a promessa de que o acusado teria sua vida preservada, sem, no entanto, informar que a pena seria o exílio perpétuo; sem informar que algum tempo depois ela seria queimada; e sem informar que poderia renunciar à obrigação de proferir a sentença, deixando a outro a tarefa de condená-lo à morte.

Manchas insensíveis ao toque de uma agulha, mamilos extras e impotência eram marcas demoníacas a serem consideradas, assim como uma mortandade de animais poderia ser atribuída ao conluio com o demônio. Para muitos, a denúncia de bruxaria acabou por tornar-se um bom argumento para se livrarem de vizinhos indesejáveis, por exemplo.

O narrador menciona o fato de que, durante os exorcismos, havia quem não acreditasse na possessão, dentre eles médicos e homens de letras que escreveram sobre Grandier após a sua morte, defendendo-o obstinadamente. Mesmo no alto clero havia quem acreditasse na sua inocência, como o Arcebispo de Bordeaux, que acreditava ser a 
"possessão" o fruto não só da influência do cônego Mignon, mas também de furor uterino.

Para que seu crime parecesse mais inominável, Grandier foi acusado não só da prática de feitiçaria, como também de participação nos ritos do sabá. Preso e enviado ao sótão da casa de Mignon, na falta de prisão adequada.

Enquanto isso, os padres começaram novas sessões de exorcismo, que se tornaram atrações turísticas, tirando as ursulinas de um longo período de miséria após a denúncia de fraude.

Dia após dia, de manhã à noite, as desgraçadas mulheres eram levadas em grupo para as diversas igrejas da cidade e executavam seus truques [...] De todas as províncias da França, e até mesmo do estrangeiro, afluíram multidões de turistas para assistir aos exorcismos. (HUXLEY, 1986, p. 157).

Na prisão, Grandier foi submetido às torturas mencionadas no Malleus:

$\mathrm{Na}$ presença de dois boticários, Grandier foi despido, completamente depilado, vendaram-lhe os olhos, e foi então sumariamente picado até o osso com uma longa e afiada sonda [...] As dores eram cruciantes, e, pelas janelas com tijolos, os gritos do prisioneiro podiam ser ouvidos por uma crescente multidão de curiosos embaixo, na rua. (HUXLEY, 1986, p. 160).

No artigo da acusação constava que apenas duas áreas de insensibilidade foram encontradas: as marcas do Diabo. No entanto, não foi registrado o modo como foram obtidas. Após a sessão de tortura, o cirurgião Mannoury virara a agulha ao contrário, para simular áreas sem sensibilidade. cometidas:

O narrador dá conta de que, na ânsia de forjar provas, algumas tolices foram

Havia momentos em que a nova doutrina era uma fonte de embaraços. Certa manhã, por exemplo, um diabo (devidamente constrangido diante do Santíssimo Sacramento) observou que o Sr. De Laubardemont era um marido enganado. $\mathrm{O}$ escrevente registrou conscienciosamente a declaração, e Laubardemont, que não estivera presente ao exorcismo, assinou a minuta sem lê-la, acrescentando o habitual post scriptum, segundo o qual, em sã consciência, considerava verdadeiro tudo o que constava do procès-verbal. Quando o caso veio à luz, houve muitas risadas maliciosas. (HUXLEY, 1986, p. 161).

No mesmo capítulo, um novo tipo de adulação é revelado: aquela feita pelo diabo ao ser pressionado pelo exorcista:

Durante o transcorrer da possessão, como o Dr. Legué observou, blasfêmias contra Deus, Cristo e a Virgem eram proferidas constantemente, mas nunca contra Luís XIII, e muito menos contra Sua Eminência. As piedosas irmãs sabiam desabafar suas tensões impunemente. (HUXLEY, 1986, p. 161). 
O capítulo 7 constitui uma digressão sobre as possíveis interpretações para o caso de Jeanne des Anges e o tratamento para a melancolia, com uma expressa recomendação ao leitor de que leia o livro de Robert Burton se quiser obter mais informações a respeito.

Qual era a teoria da natureza humana, sob que aspecto os contemporâneos de Grandier interpretavam o comportamento cotidiano e os acontecimentos estranhos, tais como os de Loudun? As respostas para essa pergunta estão contidas nas palavras de Robert Burton, cujos capítulos sobre a anatomia da alma incluem um resumo breve e notavelmente lúcido que todos, antes da época de Descartes, aceitavam praticamente como um axioma. (HUXLEY, 1986, p. 165).

Ao analisar o caso da Madre Superiora, o narrador menciona o tratamento dado a Srta. Beauchamp, que aparentemente sofria do mesmo mal, ou seja, apresentava sintomas de uma dupla personalidade, e fora curada pelo Dr. Morton Prince, "que encarava os estranhos fatos sob a luz de uma bem fundamentada teoria da atividade mental do subconsciente e técnicas de hipnose" (HUXLEY, 1986, p. 167).

Menciona, também, o modo como o Marquês de Couldray-Montpensier arrancou suas duas filhas das mãos dos exorcistas e "manteve-as bem alimentadas e chicoteou-as bastante"; como consequência, "o Demônio abandonou-as rapidamente" (HUXLEY, 1986, p. 170). No entanto, "para a simples neurose ou histeria, o açoite não era o tratamento invariável", pois as teorias médicas da época afirmavam que a causa era "o excesso de bílis negra no lugar errado" (HUXLEY, 1986, p. 171).

O narrador não se furta a expressar sua opinião sobre os demônios de Loudun:

\begin{abstract}
Os historiadores católicos modernos são unânimes em admitir que Grandier era inocente do crime pelo qual foi julgado e condenado; entretanto alguns deles - mencionados pelo abade Brémond em sua Histoire littéraire du sentimento religieux em France - estão ainda convencidos de que as freiras foram vítimas de genuína possessão. Sou incapaz de entender como tal opinião pode ser mantida por alguém que tenha lido os documentos pertinentes ao caso, e que tenha ao menos uma noção sobre anomalias psicológicas. (HUXLEY, 1986, p. 181).
\end{abstract}

Muito embora a Igreja prescrevesse quatro testes para reconhecer a possessão, ou seja, o da linguagem, o da força física anormal, o de levitação e o de clarividência, eles não foram considerados no caso dos demônios de Loudun.

O narrador lembra que, igualmente, outros casos de possessão não obtiveram sucesso nos testes, como o de Marthe Bossier, em 1598, que entrava em convulsão toda vez que uma oração ou exorcismo era lido para ela. O bispo de Orléans armou-lhe uma cilada, recitando diante dela a história da matrona de Éfeso, de Petrônio, em latim, ao que a mulher reagiu rolando no chão e acusando o bispo de maltratá-la com a leitura da Bíblia Sagrada. No caso específico de Loudun, todas as freiras que desconheciam o latim eram possuídas por demônios que também não o sabiam. Para explicar o fato, um dos exorcistas franciscanos afirmou que "existem demônios cultos e ignorantes" (HUXLEY, 1986, p. 184).

Como nem a morte de Grandier pôs fim à atuação da horda demoníaca, quatro padres jesuítas foram convocados a corroborar o diagnóstico da possessão. Sem dúvida 
alguma, um artifício bem urdido para enganar o povo, que tinha os jesuítas em alta conta. Dentre eles estava o padre Surin, que, segundo o narrador, era melancólico e sofria de distúrbios psicossomáticos. Em seus escritos, Surin afirmava que, para ele, o mundo era impregnado pelo sobrenatural. Assim, quando a irmã Jeanne, que havia bisbilhotado tudo o que podia sobre a vida dele, demonstrou-lhe saber mais do que o esperado, ele acreditou que estava diante de um milagre.

Jeanne, conforme o desenrolar do romance revela, percebeu que exercia um certo domínio sobre Surin. Durante dez meses o padre se dedicou à tarefa de exorcizála. Jeanne tentou escapar, os demônios escarneceram de suas pregações, mas Surin, infatigável, prosseguiu com as orações e os sermões.

Um dia, depois de uma sessão de exorcismo em que mais uma vez viu fracassarem os seus esforços, Surin rezou, pedindo que lhe fosse permitido sofrer no lugar da prioresa. Queria sentir o que os demônios a tinham feito sentir, oferecendo-se para ser possuído no lugar dela, a fim de curá-la, de levá-la à prática da virtude. Alguns dias depois, começou a apresentar sinais de perturbação. No início, ela se manifesta apenas em seu íntimo, através de sentimentos ambivalentes: "Sinto uma grande paz, como se estivesse sob a influência divina, e, por outro lado, uma raiva dominadora, um grande ódio a Deus" (HUXLEY, 1986, p. 244). Mas há também uma espécie de cisão que o próprio Surin descreveu:

[é] como se eu tivesse duas almas, uma da quais despojada do meu corpo e do uso dos meus órgãos, que se esconde, vendo o outro, o intruso, fazer o que quer. Estes dois espíritos lutam dentro de um campo que é o meu corpo. (HUXLEY, 1986, p. 244).

Três meses depois, Surin se viu assaltado exatamente em seu corpo, jogado ao chão, em convulsões, rolando como as outras endemoninhadas, tornando-se, também ele, motivo de diversão para a plateia e de escândalo para os jesuítas.

Envolvida por sentimentos amorosos e atração sexual por Surin, Jeanne, motivada pelo desejo que ele manifestava de santificá-la, agora desejava ser conhecida como santa, ser invocada em orações e realizar milagres. E, assim como no passado apenas a velha prioresa lhe dera ouvidos, o padre jesuíta fora eleito como o espectador ideal para a sua maior representação. Do fenômeno da possessão passou ao da santidade, desenvolvendo estigmas. A pantomima continuou até que os demônios de Loudun acabaram por tornarem-se muito caros, fazendo com que o Tesouro cessasse o pagamento aos exorcistas, que, assim, foram obrigados a retornar às suas ordens; 0 bastante para os demônios sumirem de vez.

O romance enfatiza o fato de que a irmã Jeanne manteve a sua farsa até o fim, escrevendo suas confissões, sem, no entanto, mencionar o seu maior pecado: a mentira que levara um homem à Inquisição e à fogueira.

\section{4 À guisa de conclusão}

Os demônios de Loudun constitui uma obra de difícil classificação segundo os conceitos de romance histórico expostos. O narrador coloca-se claramente na posição do autor empírico, ou seja, constitui uma entidade autorizada, cuja postura revela-se similar 
àquela do texto de Ginzburg, e parece seguir o princípio unificador de toda a pesquisa micro-histórica, ou seja, a crença de que a observação microscópica de um acontecimento revelará fatores previamente não observáveis (LEVI, 1992, p. 139).

No entanto, não se pode deixar de levar em consideração que "os limites do discurso histórico são os documentos, mas na interpretação e interligação dos documentos é a imaginação que constrói a verdade possível, sobretudo quando os documentos são poucos e lacunares" (PERRONE-MOISÉS, 1992, p. 10). Em Os demônios de Loudun, Huxley preenche essas lacunas com o olhar do narrador do século $\mathrm{XX}$, pronto a refletir sobre as concepções vigentes nos século XVII, contrapondo-as àquelas do mundo contemporâneo. Ao fazê-lo, o narrador não se furta a revelar o estatuto de sua obra, mas não o faz como os narradores típicos da metaficção historiográfica. Fá-lo à moda do micro-historiador.

Diferentemente de um narrador como o de The French Lieutenant's Woman (1969), por exemplo, sua intrusão não é destinada à reflexão metanarrativa que confere à obra o estatuto de ficção, mas a digressões que visam contrapor épocas e percepções humanas sobre determinados acontecimentos históricos. A carência de diálogos parece reforçar esse aspecto.

O livro surge assim como um gênero híbrido, misto de romance e ensaio científico, narrado por uma entidade extradiegética que também jaz a meio-termo entre o narrador e o historiador. Curiosamente, Huxley (1986) escreveu o romance cerca de trinta anos antes do surgimento da micro-história.

Ao discutir a questão da narrativa na micro-história, Levi (1992, p. 153) afirma que a função da narrativa histórica pode ser resumida em duas características: a tentativa de demonstrar, através de um relato de fatos sólidos, o verdadeiro funcionamento de alguns aspectos da sociedade que seriam distorcidos pela generalização e a de incorporar ao corpo da pesquisa em si, as limitações documentais, as técnicas de persuasão e as construções interpretativas. Ao romper com a forma autoritária do discurso adotado pelos historiadores que apresentam a realidade como objetiva, a micro-história revela que o ponto de vista do pesquisador torna-se uma parte intrínseca do relato.

Em Os demônios de Loudun é evidente a profunda pesquisa realizada pelo autor, assim como o ponto de vista do narrador sobre os eventos narrados. Huxley também não hesita em oferecer ao leitor aspectos dos bastidores da Inquisição que foram por ele reconstruídos interpretativamente, nas lacunas documentais.

Os eventos no romance são apresentados em ordem cronológica, com algumas instâncias de prolepse e analepse, não ensejando a possibilidade de diálogos entre as personagens, de modo que a ação possa ser "testemunhada" pelo leitor.

As inúmeras digressões levam a discussões metafísicas, sociológicas e históricas, em que o narrador expressa o seu ponto de vista de modo crítico, algumas vezes irônico. Paralelamente, as muitas alusões e citações definem particularmente o narrador, e, por conseguinte, o tipo de leitor potencial. Embora adote uma postura revisionista, o romance não busca questionar a veracidade dos fatos históricos, mas discutir as diferentes interpretações existentes já à época do acontecimento empírico, e que foram, de algum modo, registradas. Por fim, o romance gira em torno de uma figura histórica específica, Urbain Grandier, cuja trajetória permite-nos refletir sobre o contexto histórico, social e político do século XVII. 
Essas considerações sobre o romance de Huxley (1986), sua especificidade e arquitetura atípica, comprovam a necessidade de uma reflexão mais profunda sobre as categorias que se abrigam sob o rótulo de romance histórico, uma vez que nenhuma das propostas de categorização mostra-se suficiente para caracterizar uma obra cujo método de elaboração é tão próximo dos processos da micro-história.

\section{REFERÊNCIAS}

BERTRAND, I. Les possédés de Loudun et Urbain Grandier: étude historique. Quatrièmeedition. Paris: Libreirie Bould et C. s.d. Disponível em: <http://archive.org/stream/lespossdesde00bert\#page/n0/mode/2up> Acesso em: 19 de abr. 2012.

BRAUDEL, F. Écrits sur l'histoire. Paris: Flammarion, 1969.

BRUCE, H. A. Historic ghost and ghost hunters. Middlesex: Echo Library, 2009.

CHARTIER, R. A História hoje: dúvidas, desafios, propostas. Estudos históricos. Rio de Janeiro, v. 7, n. 13, 1994, p. 97-113.

FOWLES, J. The French Lieutenant's Woman. London: Jonathan Cape, 1969.

GINZBURG, C. O queijo e os vermes: o cotidiano e as ideias de um moleiro perseguido pela inquisição. Trad. por Maria Betania Amoroso. São Paulo: Companhia das Letras, 1987.

GOLDSMITH, Edmund. ed. The history of the devils of Loudun. The alleged possession of the Ursuline Nuns and the trial and execution of Urbain Grandier told by an eye-witness. Edimburg: A. Poiters, 1987.

Disponível em: <https://archive.org/stream/historyofdevilso00desn\#page/n5/mode/2up>. Acesso em: 02 jan. 2012.

GUIMARAES, Lucia Maria Paschoal. Os protagonistas anônimos da história: micro-história. Rev. Bras. Hist., São Paulo, v. 23, n. 45, jul. 2003.

Disponível em: <http://www.scielo.br/scielo.php?script=sci_arttext\&pid=S0102$01882003000100015 \& \operatorname{lng}=$ es\&nrm=iso>.

Acesso em: $10 \mathrm{dez}$. 2013. http://dx.doi.org/10.1590/S0102-01882003000100015.

HUXLEY, A. Os demônios de Loudun. São Paulo: Círculo do Livro, 1986.

HUTCHEON, Linda. Poética do pós-modernismo: história, teoria ficção. São Paulo: Imago, 1991.

LEVI, G. Sobre a micro-história. In: BURKE, Peter. A escrita da história. São Paulo: UNESP, 1992, p. 133-161.

LUKÁCS, G. O romance histórico. São Paulo: Boitempo, 2011.

Revista MOARA, n.39, p.1-18, jan./jun. 2013, Estudos Literários 
MARINHO, M. F. História e ficção ou ficção da História. In: O romance histórico em Portugal. Porto: Campo das Letras, 1999, p. 9-43.

PERRONE-MOISÉS, L. Vinte luas: viagem de Paumier de Gonneville ao Brasil. São Paulo: Cia das Letras, 1992.

RICOEUR, P. Tempo e narrativa. Tradução Roberto Leal Ferreira. Campinas: Papirus, 1997. Tomo III.

SCOTT, Walter . Waverly. Project Gutemberg Ebook. Disponível em:

<http://www.gutenberg.org/files/5998/5998-h/5998-h.htm>. Acesso em: 12 dez. 2012.

Ivanhoe. Project Gutemberg Ebook. Disponível em:

<http://www.gutenberg.org/files/82/82-h/82-h.htm>. Acesso em: 12 dez. 2012.

VAINFAS, R. Os protagonistas anônimos da história. São Paulo: Campus, 2002.

Recebido em 31/03/2013.

Aprovado em 17/10/2013. 